African Crop Science Journal by African Crop Science Society is licensed under a Creative Commons Attribution 3.0 Uganda License. Based on a work at www.ajol.info/ and www.bioline.org.br/cs DOI: http://dx.doi.org/10.4314/acsj.v24i1.18S

\title{
BIOMASS PRODUCTION AND FORAGE QUALITY OF HEAD-SMUT DISEASE RESISTANT NAPIER GRASS ACCESSIONS
}

\author{
I.W. KARIUKI, S.W. MWENDIA, F.N. MUYEKHO ${ }^{1}$, S.I. AJANGA ${ }^{2}$ and D.O. OMAYIO ${ }^{1}$ \\ Kenya Agricultural and Livestock Research Organization, Food Crops Research Institute-Muguga Centre \\ Department of Animal Production, P. O. Box 30148-00100 Nairobi, Kenya \\ ${ }^{1}$ Masinde Muliro University of Science and Technology, Department of Biological Sciences, \\ P. O. Box 190-50100, Kakamega, Kenya \\ ${ }^{2}$ Kenya Agricultural and Livestock Research Organization, Industrial Crops Research Institute-Molo Centre \\ P. O. Box 100-20106, Molo, Kenya \\ Corresponding author: Innocent.Kariuki@kalro.org, iwkariuki2002@yahoo.com.au
}

\begin{abstract}
Napier grass, commonly known as "elephant grass", is a major feed used for dairy production by smallholder farmers in eastern and central Africa. However, the productivity of the grass in the region is threatened by stunt and head-smut diseases. The objective of this study was to determine biomass yield and forage quality of headsmut resistant/tolerant Napier grass accessions, in the high and lowland environments of Kenya. A field study was undertaken at two contrasting environments. The first site was in the highlands at KALRO-Muguga (altitude 2,052 metres above sea level), while the second site was in the lowlands at KALRO-Katumani (altitude 1,600 metres above sea level). The study was initiated in November 2011 using canes to plant ten Napier grass accessions (ILRI numbers 16790, 16791, 16783, 18448, 16806, 16808, 16809, 16796, 16835, 16837) in separate $4 \mathrm{~m} \mathrm{x} 4 \mathrm{~m}$ plots. The grasses were first harvested at 23 week after planting at both sites. Subsequent harvests occurred at intervals of eight weeks after regeneration. There were eight growth cycles from $1^{\text {st }}$ November 2011 to $9^{\text {th }}$ May 2013 at each site. There were differences $(\mathrm{P}<0.05)$ between accessions in forage dry matter production that ranged from 28.8-51.2 metric tonnes ha $^{-1}$ at KALRO-Muguga and 18.1-26.7 metric tonnes ha ${ }^{-1}$ at KALROKatumani. The accessions (numbers 16783, 16796, 16806 and 16835) resistant to head-smut disease gave dry matter yields comparable to that of accession number 16791 which was the negative check. There were differences $(\mathrm{P}<0.05)$ between the accessions in neutral detergent fibre at both sites. There were differences $(\mathrm{P}<0.05)$ in nitrogen content (mean 2.6\%) at KALRO-Muguga. Accession no. 16806 was confirmed resistant to head-smut disease, while accession nos. 16783, 16796 and 16835 were tolerant to head-smut disease in glasshouse screening/ molecular studies.
\end{abstract}

Key Words: Kenya, Pennisetum purpureum, rain use efficiency

\section{RÉSUMÉ}

L'herbe de Napier, communément connue comme "l'herbe d'éléphant", est une nourriture importante utilisée pour la production laitière par les fermiers de petit cultivateur dans l'Afrique de l'est et centrale. Pourtant, la productivité de l'herbe dans la région est menacée par les maladies de cochonnerie de tête et le coup. L'objectif de cette étude était de déterminer la production de biomasse et la qualité de fourrage de cochonnerie de tête les nouvelles acquisitions d'herbe Napier résistantes/tolérantes, dans les hauts environnements et les environnements de plaine du Kenya. Des études sur le terrain ont été entreprises à deux environnements contrastants. Le premier site était dans les pays montagneux à KALRO-Muguga (l'altitude à 2,052 mètres au-dessus du niveau marin), pendant que le deuxième site était dans les plaines à KALRO-Katumani (l'altitude à 1,600 mètres au-dessus du niveau marin). L'étude a été lancée en novembre de 2011 en utilisant des cannes pour planter dix nouvelles 
acquisitions d'herbe Napier (ILRI numéro 16790, 16791, 16783, 18448, 16806, 16808, 16809, 16796, 16835, 16837) à $4 \mathrm{~m}$ séparés $\mathrm{x}$ les complots de $4 \mathrm{~m}$. Les herbes ont été d'abord récoltées à 23 semaine après le fait de planter aux deux sites. Il y avait des différences $(\mathrm{P}<0.05)$ dans le contenu d'azote (voulez dire $2.6 \%$ ) à KALROMuguga. La nouvelle acquisition No. 16806 a été confirmée résistante à la maladie de cochonnerie de tête, pendant que la nouvelle acquisition nos. 16783, 16796 et 16835 étaient tolérants à la maladie de cochonnerie de tête dans les études de projection de verrerie / les études moléculaires.

Mots Clés: le Kenya, Pennisetum purpureum, l'efficacité d'utilisation de pluie

\section{INTRODUCTION}

Napier grass (Pennisetum purpureum Schumach) grows in relatively moist areas $(750-2500 \mathrm{~mm}$ annual rainfall) in tropical and sub-tropical ecological zones (Lowe et al., 2003). The forage crop is popular in eastern and central Africa (Valk, 1990) for its enormous biomass production and ability to tolerate frequent cuttings (Lowe et al., 2003; Nyambati et al., 2011). In Kenya, the crop is used by smallholder dairy farmers either fresh or in silage forms as the major livestock feed (Martha et al., 2004; Orodho, 2006). These smallholder dairy farmers supply $80 \%$ of the total marketed milk in the region (Omore et al., 1999).

Despite its importance as a fodder crop for boosting the milk industry, the crop faces production challenges, with pests and diseases being the most prevalent (Farrell et al., 2002; Mwendia et al., 2007). Napier head-smut, Napier stunt and snow mold are the most common diseases (Farrell et al., 2002; Orodho, 2006). Stunt disease can reduce Napier grass yield up to $100 \%$ (Mulaa et al., 2010); while head-smut disease reduces Napier grass yields by up to $46 \%$ in Kenya (Farrell et al., 2000). The two diseases are also major problems in many parts of eastern Africa (Mulaa et al., 2010).

Napier head-smut disease is widespread in the central region of Kenya, where over $70 \%$ of the smallholder dairy farmers grow the grass (Mwendia et al., 2007). Moreover, the spread of the disease to other parts of the country is a major concern (Lukuyu et al., 2012). Napier head-smut disease is caused by a fungus [Ustilago kamerunensis P. \& H. Sydow] (Farrell, 1998; Farrell et al., 2000; Orodho, 2006; NAFIS, 2012). The disease firstly manifests itself in susceptible hosts, through induced premature flowering covered in a black mass of ustilospores (Fig. 1). This occurs even in plants that are below 1.5 metres in height, which is not usually the case in healthy plants that usually flower at heights above 1.5 to 8 metres, depending on the grass variety (Farrell, 1998). This first visual sign is later compounded by other severe symptoms, such as slow regrowth after cutting, withering and chlorosis setting in with gradual browning leading to drying and death of the entire stool of the crop within the subsequent 2-3 cuttings in severe cases (ASARECA, 2010; NAFIS, 2012). Other secondary characteristics of the disease are induced dwarfing (characterised by short internodes with distorted leaves that are reduced in number and size), increased tillering and eventual reduction in the total dry matter of the affected crop (Farrell et al., 2002; Mwendia et al., 2007; NAFIS, 2012).

The two ways through which the disease spreads to new areas are, firstly, through the spores from smutted heads of susceptible cultivars; and secondly, through exchange and transfer of planting materials (infected canes or splits) between farmers unaware that the systemic intercellular pathogen is within the tissues (Mwendia et al., 2007; ASARECA, 2010; NAFIS, 2012).

Therefore, to mitigate the spread of the disease, the two head-smut disease resistant/ tolerant cultivars (Kakamega 1 and 2) were developed (Orotho, 2006). However, the two cultivars are over-relied upon and are highly susceptible to Napier stunt disease (Arocha et al., 2009). Moreover, these two cultivars provide a narrow range of resistance genes, to the headsmut pathogen with an imminent threat of a likely evolving pathogen (NAFIS, 2012). Furthermore, the on-going expansion of the dairy industry has been almost entirely into drier zones; which demands deployment of suitable Napier grass cultivars, with resistance/tolerance to drought conditions and head-smut disease. 


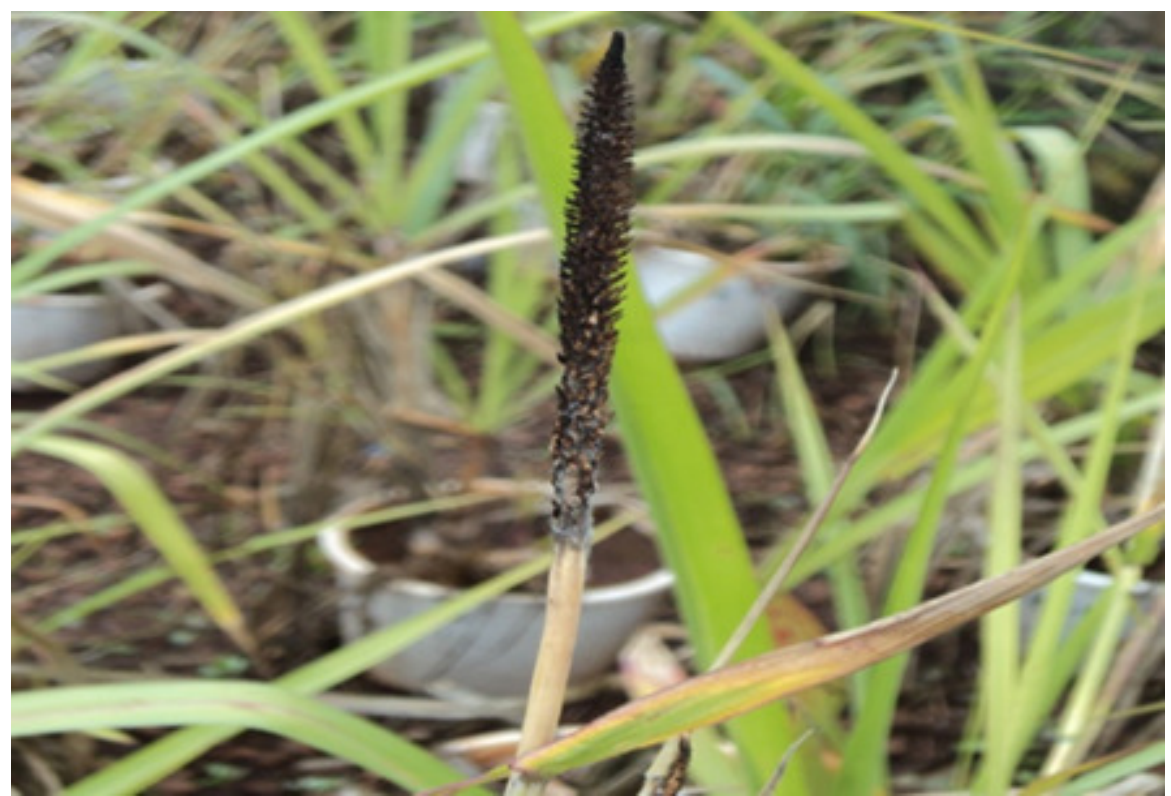

Figure 1. A smutted Napier grass crop head (Source: Omayio et al., 2014).

The objective of this study was to determine biomass yield and forage quality of head-smut resistant/tolerant Napier grass accessions in the highland and lowland environments of Kenya.

\section{MATERIALS AND METHODS}

Sites description. A field study was undertaken in two contrasting environments in Kenya. The first site was in the highlands at KALRO-Muguga [01 ${ }^{\circ} 12.663$ ' S; $036^{\circ} 38.286^{\prime}$ E; 2,052 metres above sea level]; while the second site was in the lowlands at KALRO-Katumani $\left[01^{\circ} 35.212^{\prime}\right.$ S; $037^{\circ}$ 14.407' E; 1,600 metres above sea level] (Jaetzold et al., 2006). KALRO-Muguga has mean daily temperature of $17.6^{\circ} \mathrm{C}$ and an annual rainfall of $878 \mathrm{~mm}$ (Jaetzold et al., 2006). KALRO-Katumani experiences mean daily temperature of $24.7^{\circ} \mathrm{C}$ and an annual rainfall of $655 \mathrm{~mm}$ (Jaetzold et al., 2006). Table 1 presents some properties of the soils at KALRO-Muguga and KALRO-Katumani as assessed through the procedures described by Okalebo et al. (2002).

Treatments and design. The treatments were ten Napier grass accessions at each site. The Napier grass accessions used, that differed in origin, were obtained from the field gene bank at the International Livestock Research Institute (ILRI) in Ethiopia where they had been assigned accession numbers 16790, 16783, 18448, 16806, 16808, 16809, 16796, 16835 and 16837. Accession no. 16791 (Kakamega 1) is resistant to head-smut disease (Orotho, 2006) and was used as the negative check at each site.

At each site, the ten accessions were planted in separate $4 \mathrm{~m} \times 4 \mathrm{~m}$ plots, arranged in a randomised complete block design (RCBD), in four replicates.

\section{Field study establishment and maintenance.} Land preparation was undertaken in mid-October 2011 and involved ploughing with a tractor-drawn disc plough to $0.25 \mathrm{~m}$ depth; followed by harrowing. Each plot was supplied with diammonium phosphate [DAP] fertiliser (18:46:0 of $\mathrm{N}, \mathrm{P}, \mathrm{K})$ at a rate of $26 \mathrm{~kg} \mathrm{Pha}^{-1}$ at planting. The Napier grass canes, with at least three nodes, were planted by pushing the canes into the soil at an angle of about $45^{\circ}$ to bury two nodes. Planting was done at a spacing of $1 \mathrm{~m} \mathrm{x} 1 \mathrm{~m}$, i.e. from row to row and cane to cane. Hence, each plot had 16 canes/stools.

The plots were kept weed-free with a hand hoe, when needed. Calcium ammonium nitrate [CAN] top-dress fertiliser $(26 \% \mathrm{~N})$ was applied at 
TABLE 1. Selected chemical properties of the topsoil at the study sites at KALRO-Muguga and KALRO-Katumani in Kenya

\begin{tabular}{lcccccc}
\hline Site & $\begin{array}{c}\text { Soil layer } \\
(\mathrm{m})\end{array}$ & $\begin{array}{c}\mathrm{pH} \\
\left(\mathrm{H}_{2} \mathrm{O}\right)\end{array}$ & $\mathrm{N}(\%)$ & $\mathrm{OC}(\%)$ & $\left.\mathrm{EC}(\mathrm{dS} \mathrm{m})^{-1}\right)$ & $\begin{array}{c}\text { Bulk density } \\
\left(\mathrm{kg} \mathrm{m}^{-3}\right)\end{array}$ \\
\hline KALRO-Muguga & $0-0.2$ & 5.81 & 0.18 & 2.72 & 0.183 & 1,030 \\
& $0.2-0.4$ & 5.92 & 0.13 & 1.61 & 0.231 & 1,160 \\
KALRO-Katumani & $0-0.2$ & 5.79 & 0.07 & 1.23 & 0.145 & 1,220 \\
& $0.2-0.4$ & 5.95 & 0.06 & 1.13 & 0.105 & 1,510 \\
\hline
\end{tabular}

$\mathrm{N}=$ nitrogen; $\mathrm{OC}=$ organic carbon; $\mathrm{EC}=$ electrical conductivity and each value is a mean of 4 measurements

a rate of $13 \mathrm{~g}$ per stool (equivalent to $33.8 \mathrm{~kg} \mathrm{~N}$ $\mathrm{ha}^{-1}$ ) after each harvest (cycle). No symptoms of disease and/or pest infestation were observed during the entire trial period. The grass was first harvested at week 23 when it attained an approximate height of $50 \mathrm{~cm}$ at KALRO-Muguga and $20 \mathrm{~cm}$ at KALRO-Katumani. Subsequent harvests occurred at intervals of eight weeks after regeneration. Data collection was for eight growth cycles (from $1^{\text {st }}$ November 2011 to $9^{\text {th }}$ May 2013) at each site. At the end of each growth cycle, several variables were measured.

Plant height and number of tillers. Measurements of plant height and number of tillers were undertaken a day before biomass harvest, at the end of each of the first five growth cycles. Two stools were randomly selected from each of the 40 plots. Plant height was determined as the distance from the base to the apical meristem on two randomly selected tillers per stool. The number of tillers was assessed by counting all the tillers on the two stools. The relationship between plant heights or number of tillers and forage yields was determined using Scatter charts.

Dry matter yields. The above ground dry matter (DM) yield, was determined at the end of every growth cycle, which was at 23 weeks after planting for the first growth cycle; and after eight weeks of re-growth for subsequent cycles. At each harvest, the four stools at the middle of each plot were cut at two $\mathrm{cm}$ above the ground. The stools were weighed fresh using a spring balance; then sub-samples of about five tillers were taken from the stools and weighed fresh after which they were oven-dried at $60{ }^{\circ} \mathrm{C}$ for 48 hours (AOAC, 1990) to give dry weights. These fresh and dry weights were used to calculate total dry matter yields for each plot and, thereafter, converted to metric tonnes per hectare.

Neutral detergent fibre and nitrogen content. The forage samples, resulting from the determination of dry weights, were ground using a laboratory mill (Wiley mill) to pass through 1 $\mathrm{mm}$ sieve screens. The ground samples were used to determine neutral detergent fibre (NDF) using an Ankom Fibre analyzer (Ankom Technology Fairport, NY, USA), according to AOAC (1975) procedure. Likewise, nitrogen percentage was determined on the ground samples, according to AOAC (1980) with a segmented flow analyser (Skalar segmented-flow autoanalyzer, VW Scientific, York).

Validation of resistance/tolerance of Napier grass accessions to head-smut disease. Besides assessing the productivity and forage quality of the Napier grass accessions, it was necessary to establish their resistance/tolerance to head-smut disease following artificial inoculation with Ustilago kamerunensis spores in glasshouse screening experiments up to the $11^{\text {th }}$ growth cycle at KALRO-Muguga (Omayio et al., 2014). Thereafter, the resistance/tolerance needed to be validated by a discriminative molecular method using primers in conventional Polymerase Chain Reaction (PCR) analysis at the KALRO Biotechnology Research Institute Headquarters at Muguga (Omayio et al., 2014). 
Data analysis. All data from the field study were checked for entry errors in Microsoft Excel. The data from each site were analysed independently, through analysis of variance (ANOVA), using GenStat Version 14 (VSN International Ltd). Where statistical significance $(\mathrm{P}<0.05)$ was observed, pairs of means were compared using the Least Significant Difference (LSD) test.

\section{RESULTS AND DISCUSSION}

Plant height and number of tillers. Table 2 shows that plant heights at harvesting of Napier grass accessions at KALRO-Muguga were higher than at KALRO-Katumani $(0.459 \mathrm{~m} v s .0 .266 \mathrm{~m}$, respectively). Similarly, tiller density at harvest at KALRO-Muguga was higher than at KALROKatumani (132.1 vs. 82.8, respectively) as shown in Table 2. The differences observed at the two sites were likely due to higher moisture and nitrogen content in the soil (Table 1) at KALROMuguga. In this study, there was poor relationships (Trendline equations and $\mathrm{R}^{2}$ values on scatter charts not shown) between either plant heights or tiller densities and forage production (Table 3) at either KALRO-Muguga or KALROKatumani trial sites. Similarly, Ansah et al. (2010) observed that plant height and tiller number of ILRI accession numbers 16798, 16786 and 16840 at harvesting had no relationship with forage yield in Ghana.

Dry matter yields. Table 3 shows differences $(\mathrm{P}<0.05)$ between the accessions in forage dry matter production, ranging from 28.8-51.2 $\mathrm{t} \mathrm{ha}^{-1}$ at KALRO-Muguga and 18.1-26.7 $\mathrm{t} \mathrm{ha}^{-1}$ at KALRO-Katumani. Napier grass accessions numbers $16783,16796,16806$ and 16835 resistant/ tolerant to head-smut disease gave dry matter yields comparable to that of accession no. 16791 which was the negative check at each site.

The cumulative biomass yields, during the study period, reflected total rainfall received (Data not shown) at the sites. The average dry matter yield of $21.9 \mathrm{tha}^{-1}$ at KALRO-Katumani was $53.4 \%$ of that obtained at KALRO-Muguga. This resulted in a remarkable similarity in rain use efficiency, calculated as amount of forage dry matter produced divided by total amount of rainfall. For the two sites, the corresponding values were $20.73 \mathrm{~kg} \mathrm{ha}^{-1} \mathrm{~mm}^{-1}$ at KALROKatumani and $20.71 \mathrm{~kg} \mathrm{ha}^{-1} \mathrm{~mm}^{-1}$ at KALROMuguga. Unfortunately, the rain use efficiency was not derived under controlled conditions,

TABLE 2. Plant height ( $\mathrm{m}$ ) and tiller density (No. of tillers $\mathrm{m}^{-2}$ ) at harvest of Napier grass accessions at KALRO-Muguga and KALRO-Katumani in Kenya

\begin{tabular}{|c|c|c|c|c|}
\hline \multirow[t]{2}{*}{ Napier grass accession } & \multicolumn{2}{|c|}{ Plant height (m) } & \multicolumn{2}{|c|}{ Tiller density (No. of tillers $\mathrm{m}^{-2}$ ) } \\
\hline & KALRO-Muguga & KALRO-Katumani & KALRO-Muguga & KALRO-Katumani \\
\hline $16783 \S$ & 0.51 & 0.25 & 96.6 & 75.2 \\
\hline 16790 & 0.51 & 0.26 & 69.2 & 76.3 \\
\hline $16796 \S$ & 0.45 & 0.27 & 106.9 & 69.5 \\
\hline $16806 \S$ & 0.38 & 0.22 & 169.6 & 97.3 \\
\hline 16808 & 0.37 & 0.27 & 100.5 & 77.9 \\
\hline 16809 & 0.54 & 0.27 & 236.0 & 96.0 \\
\hline $16835 \S$ & 0.37 & 0.21 & 123.4 & 82.3 \\
\hline 16837 & 0.44 & 0.28 & 103.0 & 60.7 \\
\hline 18448 & 0.46 & 0.28 & 185.5 & 116.0 \\
\hline 16791 §(Kakamega 1) & 0.56 & 0.35 & 130.3 & 76.9 \\
\hline LSD & 0.18 & 0.04 & 61.3 & 36.7 \\
\hline Significance level & $P<0.05$ & $P<0.05$ & $P<0.05$ & $P<0.05$ \\
\hline
\end{tabular}

$\S$ Napier grass accession resistant/tolerant to head-smut disease (Omayio et al., 2014) 
TABLE 3. Cumulative dry matter yield $\left(\mathrm{tha}^{-1}\right)$, neutral detergent fibre $(\%)$ and nitrogen $(\%)$ contents of Napier grass accessions at KALRO-Muguga and KALRO-Katumani in Kenya

\begin{tabular}{|c|c|c|c|c|c|c|}
\hline \multirow[t]{2}{*}{ Napier grass accession } & \multicolumn{2}{|c|}{ Dry matter yield (t ha-1) } & \multicolumn{2}{|c|}{ Neutral detergent fibre (\%) } & \multicolumn{2}{|c|}{ Nitrogen (\%) } \\
\hline & $\begin{array}{l}\text { KALRO- } \\
\text { Muguga }\end{array}$ & $\begin{array}{r}\text { KALRO- } \\
\text { Katumani }\end{array}$ & $\begin{array}{l}\text { KALRO- } \\
\text { Muguga }\end{array}$ & $\begin{array}{l}\text { KALRO- } \\
\text { Katumani }\end{array}$ & $\begin{array}{l}\text { KALRO- } \\
\text { Muguga }\end{array}$ & $\begin{array}{l}\text { KALRO- } \\
\text { Katumani }\end{array}$ \\
\hline $16783 \S$ & 47.9 & 23.4 & 65.3 & 65.3 & 2.5 & 2.4 \\
\hline 16790 & 20.6 & 18.8 & 62.4 & 62.4 & 2.8 & 2.6 \\
\hline $16796 \S$ & 42.1 & 24.5 & 66.1 & 67.2 & 2.4 & 2.2 \\
\hline $16806 \S$ & 51.2 & 18.7 & 63.7 & 64.3 & 2.4 & 2.3 \\
\hline 16808 & 28.8 & 19.3 & 64.5 & 63.2 & 2.6 & 2.6 \\
\hline 16809 & 50.0 & 26.7 & 63.1 & 65.0 & 2.9 & 2.5 \\
\hline $16835 \S$ & 44.2 & 20.9 & 66.7 & 64.4 & 2.3 & 2.7 \\
\hline 16837 & 41.5 & 18.1 & 63.9 & 62.6 & 2.7 & 2.6 \\
\hline 18448 & 41.2 & 26.0 & 65.0 & 64.7 & 2.5 & 2.3 \\
\hline 16791 § (Kakamega 1) & 42.0 & 22.1 & 66.7 & 65.8 & 2.5 & 2.4 \\
\hline LSD & 12.9 & 8.3 & 0.96 & 1.77 & 0.44 & 0.56 \\
\hline Significance level & $P<0.05$ & $P<0.05$ & $P<0.05$ & $P<0.05$ & $P<0.05$ & $P>0.05$ \\
\hline
\end{tabular}

$\S$ Napier grass accession resistant/tolerant to head-smut disease (Omayio et al., 2014). Dry matter yields are totals over eight growth cycles while neutral detergent fibre and nitrogen means are over five growth cycles. Eight growth cycles $=1^{\text {st }}$ November 2011 to $9^{\text {th }}$ May 2013. Five growth cycles $=1^{\text {st }}$ November 2011 to $22^{\text {nd }}$ November 2012

hence other variables e.g. differences in temperature, soil fertility, etc. between the sites may have influenced the calculated values.

Other studies using ILRI accessions (Ansar et al., 2010; Tessema et al., 2010) showed that their biomass production is influenced by the environment and management, in addition to other traits inherent in the accessions.

Forage quality. There were differences $(\mathrm{P}<0.05)$ between the accessions in neutral detergent fibre (NDF) that ranged from 62.4-66.7\% at KALROMuguga and 62.4-67.2\% at KALRO-Katumani (Table 3). These NDF values are lower than the average $71.5 \pm 7.1 \%($ mean \pm SD) and within the range $54.1-79.9 \%$ reported in literature (Feedipedia, 2015). Neutral detergent fibre (NDF) in forages and the total diet determines dry matter intake in ruminants (Barber et al., 2010). Ruminant diets need to be balanced to contain sufficient and effective NDF for healthy rumen function, while not providing too much fibre, as this slows down digestion and limits intake (Barber et al., 2010). Hence, although the NDF values registered by the accessions are high, the accessions can be used in total mixed rations for dairy cattle in the region.

There were differences $(\mathrm{P}<0.05)$ in nitrogen content (mean $2.6 \%$ ) between the accessions at KALRO-Muguga. However, there were no differences $(\mathrm{P}>0.05)$ in nitrogen content (mean $2.5 \%$ ) between the accessions at KALROKatumani (Table 3). The more than double the nitrogen percentage in the soil at KALROMuguga (Table 1), at the start of the trial could explain the slightly higher tissue nitrogen at this site, compared with KALRO-Katumani. Tissue nitrogen is a good measure of crude protein (Claessens et al., 2005; Moran, 2012).

The forage nitrogen percent values registered in this study translate into crude protein values (N\% x 6.25) of $15.4 \%$ at KALRO-Katumani and $16.0 \%$ at KALRO-Muguga. These crude protein values are higher than the average $9.7 \pm 4.3 \%$ (mean \pm SD) and within the range $2.8-22.7 \%$ reported in literature (Feedipedia, 2015). All the accessions recorded a crude protein level higher than the critical level of $7 \%\left(70 \mathrm{~g} \mathrm{~kg}^{-1} \mathrm{DM}\right)$ which is necessary for voluntary feed intake in ruminants (Nori et al., 2009). Hence, the Napier 
grass accessions are suitable for feeding ruminants in the region.

Validation of resistance/tolerance of Napier grass accessions. In the glasshouse experiments, besides accession 16791 (Kakamega 1) which was the negative check, only accession numbers $16806,16783,16835$ and 16796 were still free of head-smut disease at the $11^{\text {th }}$ growth cycle. The molecular study confirmed Napier grass accession 16806 to be resistant to head-smut disease, while accession numbers 16783, 16835 and 16796 were tolerant to head-smut disease (Omayio et al., 2014). In the molecular study, the detection of the pathogen in the accessions, despite their being smut-free under glasshouse experiments at conditions upon artificial inoculation, could be due to internal resistance mechanisms that do not favour the aggressive establishment of the pathogen in these accessions, unlike in the susceptible accessions in a classical case of polygenic (quantitative) resistance (Keane, 2012). An example of such internal mechanisms has been reported in sugarcane, attacked by the sugarcane smut (Ustilago scitaminea Sydow), where the crop produced increased levels of glycoproteins, with cytoagglutination properties as a defence against the pathogen's proliferation (Blanca et al., 2002; Ana-Maria et al., 2005). Furthermore, in pearl millet (Pennisetum glaucum [L.] R. Br.), similar biochemical defences have been observed against downy mildew infection (Niranjan et al., 2012). Accession no. 16806 had no pathogen detected in its tissues, which can be attributed to complete resistance or immunity, which is the top most level of resistance that is characterised by complete absence of the pathogen and disease (Van der Plank, 1975).

\section{ACKNOWLEDGEMENT}

The authors acknowledge financial support from Eastern Africa Agricultural Productivity Project (EAAPP) and the logistical support from the Centre Director, Kenya Agricultural and Livestock Research Organization (KALRO)Muguga. The Association for Strengthening Agricultural Research in Eastern and Central
Africa is appreciated for facilitating the publication of this paper.

\section{REFERENCES}

Ana-Maria, M., Blanca, F., Maria-Estrella, L. and Carlos, V. 2005. Glycoproteins from sugarcane plants regulate cell polarity of Ustilago scitaminea teliospores. Journal of Plant Physiology 162: 253-265.

AOAC. 1975. Official methods of analysis. $12^{\text {th }}$ edn. Association of Official Analytical Chemists: Washington, DC., USA.

AOAC. 1980. Official methods of analysis. $13^{\text {th }}$ edn. Association of Official Analytical Chemists: Washington, DC., USA.

AOAC. 1990. Official methods of analysis. 15th edn. Association of Official Analytical Chemists, Washington, DC., USA.

Ansar, T., Osafo, E.L.K. and Hansen, H.H. 2010. Herbage yield and chemical composition of four varieties of Napier grass (Pennisetum purpureum) grass harvested at three different days after planting. Agriculture and Biology Journal of North America 1: 923-929.

Arocha, R.Y., Lucas, J. and Obura, E. 2009. Manual of diagnosis Napier grass stunt and smut. Association for Strengthening Agricultural Research in Eastern and Central Africa, Napier grass smut and stunt resistance project number: 06/RC01-FC-2-02.

Association of Strengthening Agricultural Research in East and Central Africa. (ASARECA). 2010. Workshop final report on Mitigating the Impact of Napier Grass Smut and Stunt Diseases for the Smallholder Dairy Sector-sharing Results.1-3 June, 2010. ILRI, Addis Ababa, Ethiopia.

Barber, D. Anstis, A. and Posada, V. 2010. Factors affecting feed intake. Technical note 4 . The State of Queensland. Department of Employment, Economic Development and Innovation (DEEDI). www.deedi.qld.gov.au

Blanca, F., Agustina, M., Carlos, W.R., Dolores, P., Maria, F., Solars, C.V. and Maria, E.L. 2002. A role for sugarcane glycoproteins in the resistance of sugarcane to Ustilago scitaminea. Plant Physiology and Biochemistry 40: 881-889. 
Claessens, A., Michaud, R., Bélanger, G. and Mather, D.E. 2005. Leaf and stem characteristics of Timothy plants diversity selected for the ratio of lignin to cellulose. Crop Science 45: 2425-2429.

Farrell, G. 1998. Towards the management of Ustilago kameruniensis, a smut pathogen of Napier grass in Kenya. PhD Thesis, University of Greenwich, United Kingdom.

Farrell, G., Simons, S.A. and Hillocks, R.J. 2000. A novel technique for measuring biomass loss in a diseased tussock grass. Tropical Grasslands 34: 118-124.

Farrell, G., Simons, S.A. and Hillocks, R.J. 2002. Pests, diseases and weeds of Napier grass, Penisetum purpureum: A review. International Journal of Pest Management 48: 39-48

Feedipedia .2015. Animal Feed Resources Information System. Website: http:www.feed ipedia.org. Accessed on $2^{\text {nd }}$ March 2016.

GenStat. 2011. GenStat statistical software, version 14 for windows. VSN International Ltd, Hertfordshire, UK.

Jaetzold, R., Schmidt, H., Hornetz, B. and Shisanya, C. 2006. Farm management handbook of Kenya. Vol. II. Natural conditions and farm management information. $2^{\text {nd }}$ edn. Part B - Central Kenya and Part C East Kenya. Ministry of Agriculture, Nairobi, Kenya.

Keane, P.J. 2012. Horizontal or generalized resistance to plant pathogens in plants. In: Joseph R.L. (Ed.) Plant pathology, ISBN: 978953-51-04896. Website: http://www.intech open.com/books/plant-pathology/ Horizontal-or-generalized-resistance-toplant-pathogens-in-plants.

Lowe, A.J., Thorpe, W., Teale, A. and Hanson, J. 2003. Characterization of germplasm accessions of Napier grass (Pennisetum purpureum and $P$. purpureum $\times P$. glaucum hybrids) and comparison with farm clones using RAPD. Genetic Resources and Crop Evolution 50: 121-132

Lukuyu, B., Gachuiri, C.K., Lukuyu, M.N., Lusweti, C. and Mwendia, S. (Eds.). 2012. Feeding dairy cattle in East Africa. East Africa Dairy Development Project, Nairobi, Kenya.
Martha, G.B., Corsi, M., Trivelin, O.C.P. and Alves, C.M. 2004. Nitrogen recovery and loss in a fertilized elephant grass pasture. Grass and Forage Science 59: 80-90.

Moran, J. 2012. Managing high grade cows in the tropics. CSIRO Publishing Victoria, Australia.

Mulaa, M., Awalla, B., Hanson, J., Proud, J., Cherunya, A., Wanyama, J., Lusweti, C. and Muyekho, F. 2010. Stunting disease incidence and impact on Napier grass (Pennisetum purpureum Schumach) in Western Kenya. In: Proceedings of the $12^{\text {th }}$ KARI Biennial conference. pg 937-943. http://www.kari.org/ biennial conference/conference12/docs

Mwendia, S.W., Wanyoike, M., Wahome, R.G. and Mwangi, D.M. 2007. Effect of Napier head smut disease on Napier yields and the disease coping strategies in farming systems in central Kenya. Livestock Research for Rural Development 19:109

National Farmers Information Services (NAFIS). 2012. A Facilitation of NALEP and Ministry of Agriculture Kenya. Website: http:// www.nafis.go.ke/fodders/napier-grass. Accessed on $28^{\text {th }}$ July 2012.

Niranjan, R.S., Lavaya, S. and Amruthesh, K. 2012. Histo-chemical changes induced by PGPR during induction of resistance in pearl millet against downy mildew disease. Biological Control 60: 90-102.

Nori, H., Sani ,S. A. and Tuen, A. A. 2009. Chemical and physical properties of Sarawak (East Malaysia) rice straws. Livestock Research for Rural Development. Volume 21, Article \#122.

Nyambati, E.M., Lusweti, C.M., Muyekho, F.N. and Mureithi, J.G. 2011. Up-scaling Napier grass (Pennisetum purpureum Schum) production using "Tumbukiza" method in smallholder farming systems in north-western Kenya. Journal of Agricultural Extension and Rural Development 3: 1-7.

Okalebo, J.R., Gathua, K.W. and Woomer, P.L. 2002. Laboratory methods of soil and plant analysis: A working manual ( $2^{\text {nd }}$ Edition). TSBF-CIAT and SACRED Africa, Nairobi, Kenya.

Omayio, D.O., Ajanga, S.I., Muoma, J.V., Muyekho, F.N. and Kariuki, I. 2014. Internal 
Transcribed Spacer Primers Detect Better Ustilago kamerunensis; A Napier Grass Head Smut Pathogen Constraining the Dairy Sector in Eastern Africa. Journal of Agri-Food and Applied Sciences, Available online at jaas.blue-ap.org (O2014 JAAS Journal. Vol. 2(9), pp. 265-274, 30 September, 2014 E-ISSN: 2311-6730.

Omore, A., Muriuki, H., Kenyanjui, M., Owango, M. and Staal, S.J. 1999. The Kenya dairy subsector: A rapid appraisal. MoA/KARI/ILRI smallholder dairy (R\&D) Project report, Nairobi, Kenya. 51pp.

Orodho, B.A. 2006. The role and importance of Napier grass in the smallholder dairy industry in Kenya. http://www.fao.org/AG/AGP/ AGPC/doc/newpub/ napier/napierkenya

Skerman, P.J. and Riveros, F. 1990. Tropical Grasses. FAO Plant Production and Protection series No. 23. FAO, Rome, Italy.
Staal, S., Chege, L., Kenyanjui, M., Kimari, A., Lukuyu, B., Njumbi, D., Owango, M., Tanner, J., Thorpe, W. and Wambugu, M. 1998. A cross-section survey of Kiambu district for the identification of target groups of smallholder dairy producers. KARI/ILRI collaborative project report, Nairobi, Kenya.

Tessema, Z.K., Mihret, J. and Solomon, M. 2010. Effect of defoliation frequency and cutting height on growth, dry matter yield and nutritive value of Napier grass (Pennisetum purpureum (L.) Schumach). Grass and forage science 65:421-430.

Valk, Y.S. 1990. Review report of the DEAF surveys during 1989. Ministry of Livestock Development, Nairobi, Kenya.

Van der Plank, E.J. 1975. Principles of plant infection. Academic Press, Inc. London, UK. 